\title{
PELATIHAN DIGITAL MARKETING UPAYA PENINGKATAN PEREKONOMIAN PADA KARANG TARUNA KECAMATAN CIOMAS BOGOR
}

\author{
Cahyani Budihartanti ${ }^{1}$, Laila Septiana ${ }^{2}$, Indah Purnamasari ${ }^{3}$, Tuslaela ${ }^{4}$, Yumi Novita Dewi ${ }^{5}$ \\ $1,2,3,4,5$ Universitas Nusa Mandiri \\ *Korespondensi: cahyani.cbh@ nusamandiri.ac.id, laila@ nusamandiri.ac.id, \\ indah.ihi@nusamandiri.ac.id, tuslaela.tll@nusamandiri.ac.id, yumi.ymd@nusamandiri.ac.id
}

\begin{abstract}
ABSTRAK. Karang taruna merupakan wadah aspirasi bagi seluruh masyarakat desa Pagelaran dan para lembaga, dimana visi dari desa Pagelaran adalah " membangun desa yang maju”. Tugas Karang taruna adalah menanggulangi berbagai masalah kesejahteraan sosial terutama yang dihadapi generasi muda, baik yang bersifat preventif, rehabilitatif, maupun pengembangan potensi generasi muda di lingkungannya. Pelatihan yang diberikan oleh Dinas Sosial dalam mengembangkan budi daya ikan dalam pemasarannya masih kurang maksimal. Oleh karena itu pada kegiatan pengabdian masyarakat ini pelatihan yang diberikan adalah edukasi mengenai pemanfaatan teknologi dalam pemasaran dalam bentuk pemasaran digital atau digital marketing. Dengan adanya pelatihan ini maka dapat menambah pengetahuan dan kemampuan para pemuda karang taruna Ciomas dalam memasarkan hasil ikan dengan memanfaatkan digital marketing sehingga dapat meningkatkan penjualan.

Kata kunci: Karang taruna, peningkatan pengetahuan, digital marketing, peningkatan penjualan

ABSTRACT. Karang Taruna is a forum for aspirations for all Pagelaran village communities and institutions, where the vision of Pagelaran village is "building an advanced village". The task of Karang Taruna is to overcome various social welfare problems, especially those faced by the younger generation, both preventive, rehabilitative, as well as developing the potential of the younger generation in their environment. The training provided by the Social Service in developing fish farming in marketing is still not optimal. Therefore, in this community service activity, the training provided is education about the use of technology in marketing in the form of digital marketing or digital marketing. With this training, it can increase the knowledge and abilities of the Ciomas youth youth groups in marketing fish products by utilizing digital marketing so that they can increase sales.
\end{abstract}

Keywords: Youth organizations, increased knowledge, digital marketing, increased sales

\section{PENDAHULUAN}

Digital marketing merupakan suatu kegiatan pemasaran/promosi suatu produk, brand maupun jasa menggunakan media digital dan internet.

Karang taruna merupakan wadah aspirasi bagi seluruh masyarakat desa Pagelaran dan para lembaga, dimana visi dari desa Pagelaran adalah " membangun desa yang maju”. Aktifnya kegiatan pemuda dan pemudi karang taruna Kecamatan Ciomas dimaksudkan untuk mewujudkan misi dari Desa Pagelaran yaitu[1] : meningkatkan Infratrukstur Pedesaan, meningkatkan Perekonomian Pedesaan, meningkatkan Perekonomian Usaha Kecil/Alas kaki, Meningkatkan Pelatihan dan Keterampilan.

This work is licensed under a Creative Commons Attribution-NonCommercial-ShareAlike 4.0

International License. 
Meningkatkan Pelatihan dan Keterampilan.Karang Taruna Desa Pagelaran Kecamatan Ciomas merupakan salah satu pendukung dalam berkembangnya pemerintahan Desa. Karang Taruna Ciomas, berfungsi sebagai penyalur kegiatan masyarakat, dan pelengkap pemerintahan desa terutama dalam menggandeng pemuda desa.

Selain menjalankan visi dan misi Desa Pagelaran Kecamatan Ciomas, Tugas Karangtaruna adalah untuk menanggulangi berbagai masalah kesejahteraan sosial terutama yang dihadapi generasi muda, baik yang bersifat preventif, rehabilitatif, maupun pengembangan potensi generasi muda di lingkungannya [2].

Pada tanggal 22 November 2019, Dinas Sosial telah mengadakan Pelatihan Usaha Kesejahteraan Sosial (UKS) di aula Kecamatan Ciomas, di mana tema yang diusung adalah mengembangkan potensi anak muda [3]. Pemerintah mengembangkan budi daya ikan pada wilayah Ciomas, karena kandungan PH pada air yang sangat cocok untuk budi daya ikan.

Dalam melakukan pemasaran ikan maupun bibit ikan yang dilakukan pemuda Karang Taruna masih bersifat konvensional, belum merambah dalam dunia digital sehingga omset yang didapat pun tidak lah maksimal.

Hal ini merupakan salah satu masalah yang sedang dihadapi oleh pemuda karang taruna. Berdasarkan misi dan tugas Karang Taruna yang diemban, Pemuda Karang Taruna harus dapat mengikuti perkembangan teknologi. Oleh karena itu pada kegiatan pengabdian masyarakat kali ini, kami memberikan pelatihan digital marketing. Digital marketing adalah menggunakan internet sebagai media pemasaran [4]. Dimana dalam digital marketing mempunyai beberapa keunikan yaitu [5]:

1. Interaktivitas: konsumen dapat menentukan waktu untuk memulai berinteraksi (login ke internet) dan jangka waktu koneksi.

2. Memperkuat dampak pemasaran karena internet dapat meningkatkan jangkauan pasar dan mudah untuk digunakan oleh UMKM.

3. Konsumen menjadi tidak berbatas. Setiap orang yang terkoneksi dengan internet di dunia dapat membuka suatu website.

4. Informasi online tersedia secara terus menerus selama 24 jam sehari, 7 hari seminggu dan seterusnya.

5. Pendekatan kepada konsumen dilakukan secara aktif. Konsumen yang memutuskan apakah akan menggunakan produk / jasa yang ditawarkan atau tidak.

6. Terjadi diskusi dengan konsumen atau diskusi antar konsumen. Pengguna internet dapat saling berdiskusi dan bebas mengemukakan pendapat mereka tentang suatu produk / jasa.

7. Mengandung banyak sekali informasi / data dan sangat mungkin untuk melakukan perbaharuan data (up date) jika diperlukan.

8. Lebih mudah diukur karena menggunakan teknologi digital dari pada pemasaran tradisional.

9. Mudah beradaptasi. Pemasaran digital sangat mudah mengubah konten website berdasarkan masukan / saran dari konsumen.

10. Personalisasi. Pemasaran digital mampu membuat penawaran dan program yang dapat disesuaikan berdasarkan profil atau perilaku konsumen dan kesukaan konsumen.

This work is licensed under a Creative Commons Attribution-NonCommercial-ShareAlike 4.0

International License. 
EmaiL: info@stmik.jayakarta.ac.id , tridharmadimas.jayakarta@gmail.com DOI : 10.52362/tridharmadimas.v1i2.653/halaman : 102-108

E-ISSN: 2798-8295 (Online), P-ISSN: 2798-8554 (Print) Vol. 1, No.2, Desember 2021

11. Efisiensi biaya: Pada beberapa website atau toko online, selain menyediakan produk / jasa berbayar, juga dapat ditemukan produk / jasa tidak berbayar. Pada beberapa website, trafik kunjungan dapat meningkat dengan tanpa bayaran dari pengunjung.

Berdasarkan hasil identifikasi masalah yang didapatkan, masalah yang sedang dihadapi oleh pemuda karang taruna Kecamatan Ciomas, yaitu :

1. Kurangnya Pengetahuan /edukasi dalam memanfaatkan teknologi dalam pemasaran.

2. Kurangnya pemahaman dalam menerapkan digital marketing.

Maka dengan adanya Kegiatan Pelatihan Digital Marketing ini diharapkan dapat memberikan pengetahuan tentang pentingnya menerapkan strategi pemasaran digital untuk meningkatkan omset penjualan [6] khususnya bagi para anggota Karangtaruna Kecamatan Ciomas.

\section{METODE}

Terdapat beberapa kegiatan dengan dalam upaya peningkatan perekonomian pada Karang Taruna Kecamatan Ciomas melalui pelatihan digital marketing.

Secara garis besar terdapat dua kegiatan utama yaitu identifikasi penggunaan media pemasaran yang digunakan saat ini dan kegiatan pelatihan digital marketing dalam upaya peningkatan perekonomian pada Karang Taruna Kecamatan Ciomas.

\section{HASIL DAN PEMBAHASAN}

Kegiatan pelatihan digital marketing diberikan kepada para peserta dilakukan secara daring, mengingat pemerintah masih memberlakukan peraturan PPKM untuk wilayah-wilayah tertentu.

Pada pelatihan Digital marketing ini meliputi : pengenalan dasar tentang digital marketing, jenis-jenis digital marketing, fungsi dan memaksimalkan search engine, Social Media Marketing, serta advertising pada sosial media.

Adapun tahapan pelaksanaan Kegiatan pengabdian Masyarakat ini adalah :

\section{Persiapan}

Sebelum kegiatan dilakukan panitia kegitan melakukan Identifikasi penggunaan media pemasaran yang digunakan anggota Karang Taruna Kecamatan Ciomas. Identifikasi penggunaan media pemasaran ini dilakukan untuk mengetahui kondisi yang terjadi saat ini dari para peserta pelatihan dalam menjalankan usahanya terutama dalam memanfaatkan teknologi informasi dan komunikasi.

Metode yang digunakan dalam identifikasi penggunaan media pemasaran adalah:

a. Observasi

Kegiatan observasi ini dilakukan kepada Para anggota dan penanggung jawab Karang Taruna Kecamatan Ciomas untuk mengetahui cara para anggota Karang Taruna melakukan usaha,serta untuk mengetahui berbagai permasalahan yang dihadapi dalam berusaha.

\section{cc) (1) (2)}

This work is licensed under a Creative Commons Attribution-NonCommercial-ShareAlike 4.0 International License. 
b. Wawancara

Wawancara dilakukan kepada beberapa Pengurus dan anggota Karang Taruna yang juga menjadi pelaku usaha terutama di Desa pagelaran Kecamatan Ciomas. Melalui wawancara, diperoleh informasi secara kualitiatif yang tidak diperoleh melalui kuisioner. Teknik wawancara yang dilakukan adalah dengan in-depth interview. Informasi yang diperoleh dari wawancara adalah mengenai : penggunaan teknologi dan informasi dalam melakukan usaha, infrastruktur teknologi yang dimiliki dalam menjalankan usaha, media sosial atau marketplace yang sudah digunakan, cara pemasaran yang lebih banyak digunakan, strategi pelaku usaha untuk memanfaatkan teknologi informasi dalam melakukan usaha, kesiapan sumber daya manusia dalam melakukan usaha secara online, serta kendala yang dihadapi dalam menjalankan usaha.

\section{Pelaksanaan}

Pelatihan digital marketing dalam upaya pengembangan usaha yang berbasis teknologi untuk peningkatan perekonomian Karang Taruna Kecamatan Ciomas.

Berdasarkan identifikasi pada tahap sebelumnya, maka dilakukan kegiatan pelatihan digital marketing dalam upaya pengembangan usaha yang berbasis teknologi Anggota Karang Taruna Kecamatan Ciomas.

Metode penyampaian materi yang digunakan adalah pelatihan dan pendidikan masyarakat.

a. Metode pendidikan masyarakat, dilakukan dengan menyampaikan materi dasar Digital Marketing atau pemasaran secara online. Hal ini bertujuan untuk meningkatkan wawasan pelaku usaha mengenai pentingnya digital marketing di era saat ini. Selain untuk meningkatkan wawasan, materi ini juga dilakukan untuk memberikan semangat dan motivasi kepada para anggota karang taruna dalam menjalankan serta mengembangkan usahanya.

b. Metode Pelatihan metodedilakukan pada praktek mendaftarkan akun social media seperti facebook dan Instagram, serta memaksimalkan sosial media tersebut untuk memasarkan produk mereka. Materi ini dilakukan sesuai dengan identifikasi awal yang telah dilakukan. Pelaksanaan pelatihan ini dilakukan secara daring melalui aplikasi zoom, dikarenakan kondisi pemberlakuan PPKM dalam melawan covid19. 
TRIDHARMADIMAS: Jurnal Pengabdian Kepada Masyarakat Jayakarta

http://journal.stmikjayakarta.ac.id/index.php/tridharmadimas

EmaiL: info@stmik.jayakarta.ac.id , tridharmadimas.jayakarta@gmail.com

DOI : 10.52362/tridharmadimas.v1i2.653/halaman : 102-108

E-ISSN: 2798-8295 (Online), P-ISSN: 2798-8554 (Print) Vol. 1, No.2, Desember 2021

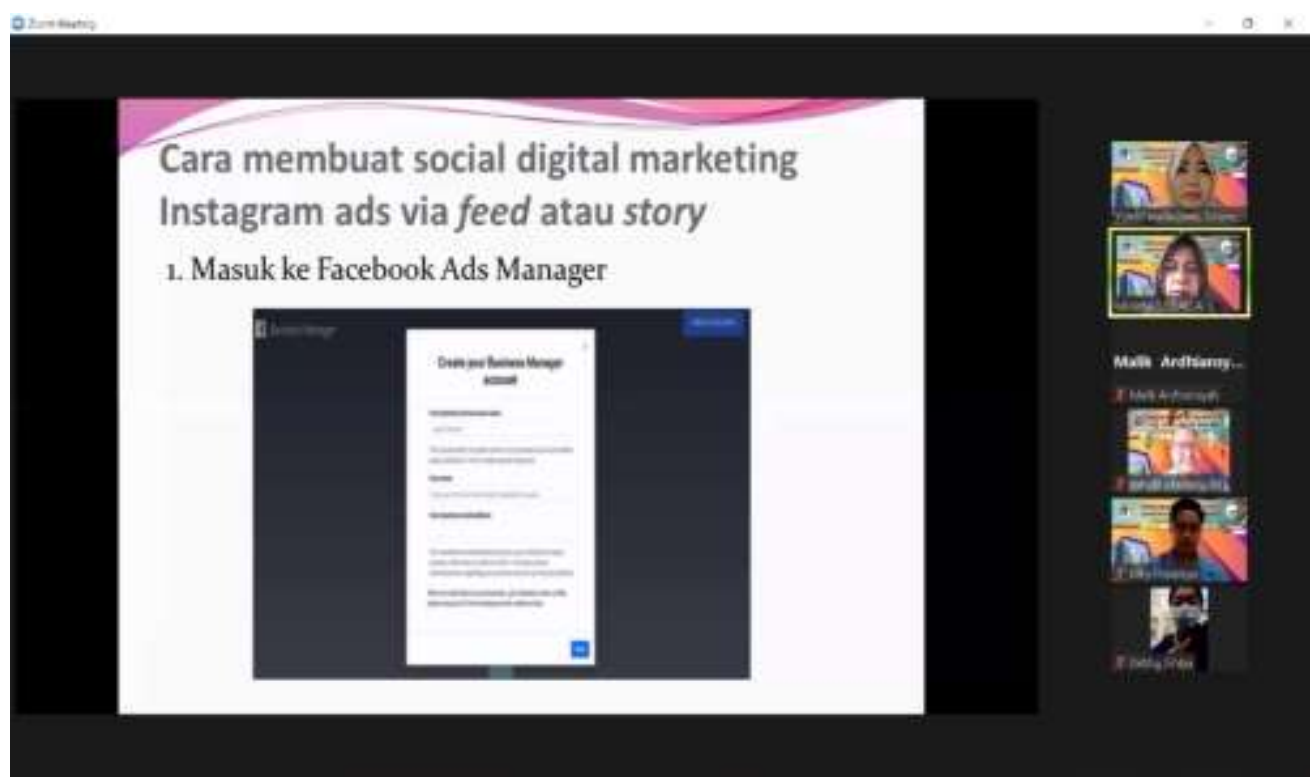

Gambar 1. Pelaksanaan kegiatan Pengabdian Masyarakat Tentang Digital Marketing untuk Peningkatan Perekonomian Bagi Anggota Karang Taruna Desa Pagelaran Kecamatan Ciomas Bogor

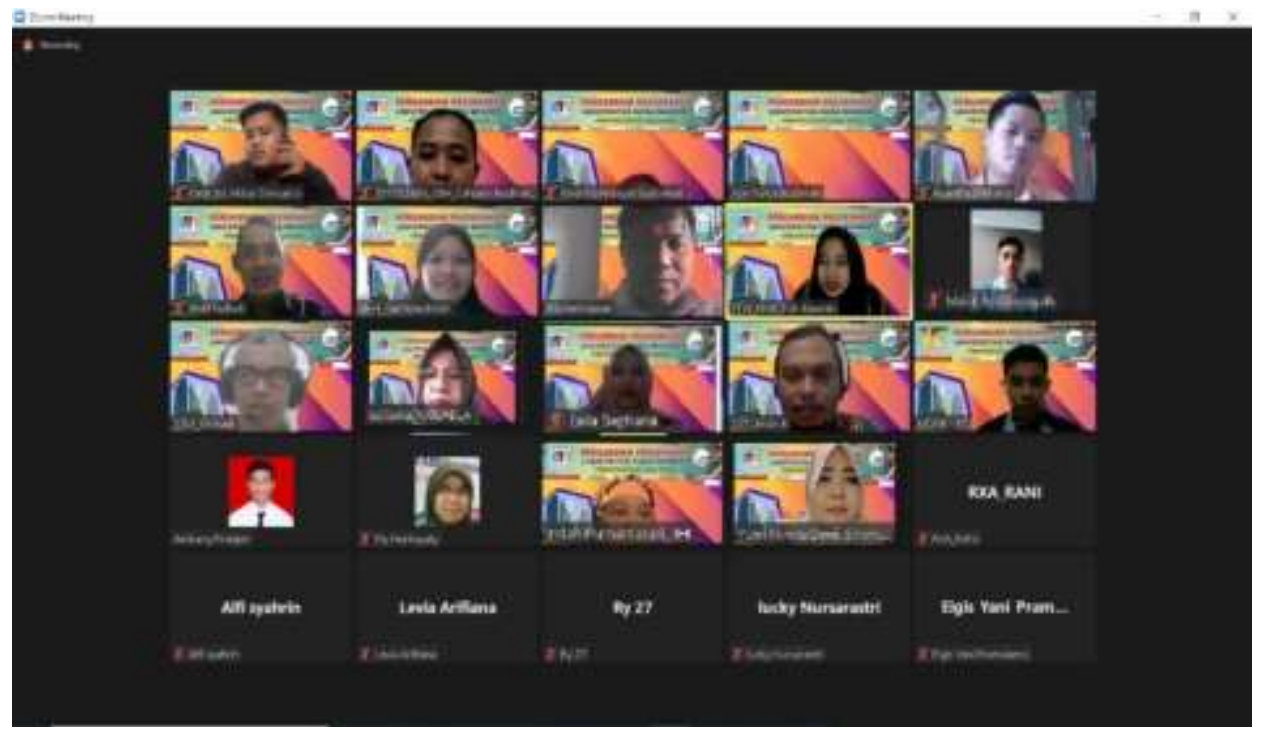

Gambar 2. Panitia dan Peserta Pelatihan Digital Marketing dalam sesi Foto Bersama

\section{Evaluasi}

Evaluasi Kegiatan Evaluasi kegiatan dilakukan untuk mengetahui feedback dari peserta pelatihan yaitu anggota karang taruna kecamatan Ciomas, berupa tanggapan dari peserta pelatihan, tindak lanjut yang akan dilaksanakan oleh peserta, juga harapan untuk kedepannya. Evaluasi dari

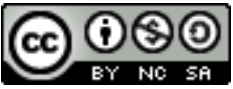

This work is licensed under a Creative Commons Attribution-NonCommercial-ShareAlike 4.0

International License. 
EmaiL: info@stmik.jayakarta.ac.id , tridharmadimas.jayakarta@gmail.com DOI : 10.52362/tridharmadimas.v1i2.653/halaman : 102-108

E-ISSN: 2798-8295 (Online), P-ISSN: 2798-8554 (Print) Vol. 1, No.2, Desember 2021

kegiatan ini juga dilakukan untuk mengetahui kesesuaian antara hasil identifikasi awal penggunaan media dalam pemasaran dengan kegiatan pelatihan yang diberikan. bentuk evaluasi kegiatan ini dilakukan dengan cara penyebaran kuisioner

Table 1. Hasil Rekapan Kuesioner Pelaksanaan Kegiatan Pelatihan

\begin{tabular}{|c|c|c|c|c|c|c|}
\hline Kode & Pertanyaan & $\begin{array}{l}\text { Sangat } \\
\text { tidak } \\
\text { setuju }\end{array}$ & $\begin{array}{l}\text { Tidak } \\
\text { setuju }\end{array}$ & $\begin{array}{l}\text { Cukup } \\
\text { setuju }\end{array}$ & Setuju & $\begin{array}{l}\text { Sangat } \\
\text { setuju }\end{array}$ \\
\hline $\mathrm{P} 1$ & $\begin{array}{l}\text { Aplikasi yang digunakan/ diperkenalkan } \\
\text { bermanfaat untuk menunjang pekerjaan } \\
\text { / usaha yang dilakukan (F2-1) }\end{array}$ & 0 & 0 & 0 & 3 & 23 \\
\hline $\mathrm{P} 2$ & $\begin{array}{l}\text { Aplikasi yang digunakan/ diperkenalkan } \\
\text { dapat mempermudah pekerjaan / usaha } \\
\text { (F2-2) }\end{array}$ & 0 & 0 & 0 & 13 & 13 \\
\hline P3 & $\begin{array}{l}\text { Aplikasi yang digunakan dapat } \\
\text { meningkatkan kualitas pelayanan }(\mathrm{F} 2-3)\end{array}$ & 0 & 0 & 0 & 26 & 0 \\
\hline $\mathrm{P} 4$ & $\begin{array}{l}\text { Aplikasi yang digunakan dapat } \\
\text { menambah wawasan (F2-4) }\end{array}$ & 0 & 0 & 0 & 0 & 26 \\
\hline P5 & User friendly (F3-1) & 0 & 0 & 0 & 20 & 6 \\
\hline P6 & Aman (F3-2) & 0 & 0 & 0 & 20 & 6 \\
\hline P7 & Tepat (F3-3) & 0 & 0 & 0 & 0 & 26 \\
\hline P8 & Cepat (F3-4) & 0 & 0 & 0 & 0 & 26 \\
\hline
\end{tabular}

\section{Pembuatan Laporan}

Hasil dari kegiatan Pengabdian Masyarakat ini adalah berupa Laporan, dan Press Release yang di publish pada media elektronik.

\section{KESIMPULAN}

Dari hasil kegiatan pengabdian masyarakat yang telah dilaksanakan tentang Pelatihan Digital Marketing Upaya Peningkatan Perekonomian pada Karang Taruna Desa Pagelaran kecamatan Ciomas, sebagai berikut :

1. Terdapat peningkatan pengetahuan dan kemampuan bagi para peserta tentang tips dan trik penjualan secara elektronik atau digital marketing untuk mendapatkan omzet yang besar dengan memanfaatkan teknologi sebagai toolsnya.

2. Para peserta dapat mengimplementasikan teori digital marketing dalam aktivitas realnya yaitu menggunakan perangkat media elektronik untuk menjual hasil budi daya ikan ke seluruh pelosok daerah sehingga adanya peningkatan penjualan yang significant.

\section{UCAPAN TERIMAKASIH (jika ada)}

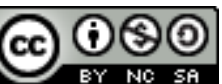

This work is licensed under a Creative Commons Attribution-NonCommercial-ShareAlike 4.0 International License. 
TRIDHARMADIMAS: Jurnal Pengabdian Kepada Masyarakat Jayakarta

http://journal.stmikjayakarta.ac.id/index.php/tridharmadimas

EmaiL: info@stmik.jayakarta.ac.id , tridharmadimas.jayakarta@gmail.com

DOI : 10.52362/tridharmadimas.v1i2.653/halaman : 102-108

E-ISSN: 2798-8295 (Online), P-ISSN: 2798-8554 (Print) Vol. 1, No.2, Desember 2021

Ucapan terima kasih kami haturkan kepada Kepala Desa Pagelaran Kecamatan Ciomas beserta staff dan jajarannya, serta kepada pengurus dan anggota Karang Taruna Desa Pagelaran Kecamatan Ciomas yang telah bekerjasama dan terlibat dalam kegiatan ini.

\section{DAFTAR PUSTAKA}

[1] NN, "Visi dan Misi Desa Pagelaran Kec. Ciomas Kab. Bogor," 2018. http://pagelaranciomas.desa.id/artikel/2018/12/11/visi-dan-misi (accessed Sep. 10, 2021).

[2] Unaidiah, "Tugas Karang Taruna," 2014. http://pagelaranciomas.desa.id/artikel/2014/4/30/karang-taruna (accessed Sep. 10, 2021).

[3] Centerweb, "Kembangkan Potensi Anak Muda, Dinas Sosial Sumbang 4000 Bibit Ikan Untuk Karang Taruna," 2019. https://zonapublik.com/kembangkan-potensi-anak-muda-dinas-sosialsumbang-4000-bibit-ikan-untuk-karang-taruna/ (accessed Sep. 01, 2021).

[4] R. K. Muljono, Digital Marketing Concept, PT. Gramed. Jakarta, 2018.

[5] T. Elida and A. Raharjo, Pemasaran Digital, Pertama. Bogor: IPB Press, 2019.

[6] B. B. Hapsoro, Palupiningdyah, and A. Slamet, "Peran Digital Marketing sebagai Upaya Peningkatan Omset,” J. Pengabdi. Masy. “ABDIMAS,” vol. 23, no. 2, pp. 117-120, 2019.

This work is licensed under a Creative Commons Attribution-NonCommercial-ShareAlike 4.0

International License. 